\title{
Upscaling a district heating system based on biogas cogeneration and heat pumps
}

\author{
Richard P van Leeuwen ${ }^{1,2^{*}}$, Jirka Fink ${ }^{2}$, Jan B de Wit ${ }^{1}$ and Gerard JM Smit ${ }^{2}$
}

\begin{abstract}
Background: The energy supply of the Meppel district Nieuwveense landen is based on biogas cogeneration, district heating, and ground source heat pumps. A centrally located combined heat and power engine (CHP) converts biogas from the municipal wastewater treatment facility into electricity for heat pumps and heat for district heating purposes. Development of the urban district is influenced by the current economic and building decline. For the district heating energy concept, a migration strategy for the required infrastructure is required. The migration spans the district's small-scale starting phase involving 40 houses up to a scale of 176 houses.
\end{abstract}

Methods: An optimization model which maximizes profitability is developed which includes data from district heating and cooling demand patterns.

Results: With the optimization model, optimal CHP size, boiler size, and operational hours are determined for various scenarios.

Conclusions: From the scenario analysis, a migration strategy is developed which starts with a simple system concept supported by boilers to a larger system which includes a CHP. Sustainability in terms of $\mathrm{CO}_{2}$ emission savings of the energy concept is compared with other possible energy concepts.

Keywords: Cogeneration; Biogas; District heating; Heat pumps; Renewable energy; Low-energy building; System migration

\section{Background}

In the Netherlands, at least $40 \%$ of the national carbon dioxide emissions are related to the heating demand of buildings. Due to the natural gas reserves, conversion by natural gas boilers dominates the heating supply for space heating and hot tap water. But natural gas reserves are gradually depleting and large-scale carbon dioxide emissions cause climate change. Hence, Dutch policies are aimed to gradually diminish the consumption of fossil fuels in general and increase the share of renewable energy. Recently, local governments take up their responsibility and create favorable policies to stimulate reduction of energy consumption and increase the share of renewable energy on a local scale. One of these initiatives is the

\footnotetext{
${ }^{*}$ Correspondence: r.p.vanleeuwen@saxion.nl

1 Sustainable Energy Group, Saxion University of Applied Sciences, Maarten Harpertsz Tromplaan 28, P.O. Box 70.000, 7500 KB Enschede, the Netherlands 2 Department of Computer Science, Mathematics and Electrical, Engineering, University of Twente, Drienerlolaan 5, P.O. Box 217, 7500 AE Enschede, the Netherlands
}

smart grid demonstration project MeppelEnergie, which is funded by the Dutch program Switch2SmartGrids. For the project's energy system, we develop a smart grid control. The Meppel energy concept consists of a biogas combined heat and power engine (CHP), backup boilers, high temperature (HT) water storage, heat pumps, and aquifer underground thermal storage. The CHP generates electric and thermal energy. The thermal energy of the CHP is used for district heating, the electricity is used to supply heat pumps placed at houses with no connection to the district heating, or is sold through the external grid.

Cooling energy for the houses is provided by an underground aquifer consisting of a warm and cold well. During the heating season, the warm well provides low temperature (LT) heat for the heat pumps. Cooling energy of the houses also provides part of the required regeneration energy to maintain temperature balance within the underground thermal storage. Another part of the regeneration is provided either by a dry cooler or an effluent stream from the municipal wastewater treatment plant (MTP).

\section{照 Springer}


Due to the recent economic recession in the Dutch housing market, the planning of the district's expansion is shifted from ambitious to a more realistic planning. The district is now built in smaller steps, i.e., phase 1 for the period up to 2015 contains 40 houses. After that, phase 2 contains another 136 houses and is built up to 2017 . Even after phase 2, the scale is not yet reached to justify all investments in the pictured energy concept. Hence, the energy concept is to be treated as a horizon relating to 300 to 400 houses in the district, which is not expected before 2020. We investigate in this paper a possible scenario for the evolution of the district heating system from a starting system with less investments for the first building phase as shown in Figure 1 up to the final system which includes aquifer thermal storage. The starting energy concept consists of heat generators which run on natural gas. It has to be determined which type of generators (boilers or a CHP with supporting boilers) are optimal in this case. Without biogas supply during the first years, integration of renewable energy is realized by purchasing certified green energy (green gas) from the grid. The starting concept also includes a refrigeration chiller to provide cooling for the houses.

The first goal of this paper is to determine the required heating and cooling generator capacity rates for a district heating and cooling system. The second goal is to determine the most economic heat converter (boiler or CHP) in relation to the number of houses. The third goal is to compare the sustainability performance of the starting energy concept with other options. Contributions of this paper are twofold, first we develop a simplified methodology to estimate heating and cooling demand data for a district heating network and a method to determine the operating time of a heating or cooling device based on such data. Second, we demonstrate the application of such methods for an integrative study on financial and sustainability aspects of a complex energy system.

The paper is structured as follows: the 'Background' section introduces the energy concept and problem statement. The 'Related work' subsection outlines work related to our investigation. The 'Methods' section defines the energy model, equations and case related parameters. The 'Results and discussion' section includes results, and finally, in the 'Conclusions' section, the conclusions are drawn.

\section{Related work}

Experience with district heating in the Netherlands is traditionally related to large-scale steam power plants (e.g., Amsterdam and Almere city heating network and many smaller city projects). More recently, decentral projects for new urban districts apply either biomass (wood) thermal conversion in boilers (e.g., muziekwijk Zwolle) or biogas cogeneration (e.g., Apeldoorn, Zeewolde, and Leeuwarden) [1]. An overview of Dutch district heating projects and profitability investigation is presented in [2].

Vallios et al. [3] develop a modeling approach for sizing biomass-fueled district heating systems. The district heating (DH) system only includes biomass boilers. Optimal size of a residential micro CHP and storage in Japan is investigated by Ren et al. [4] who apply a mixed integer nonlinear programming model. They determine optimal

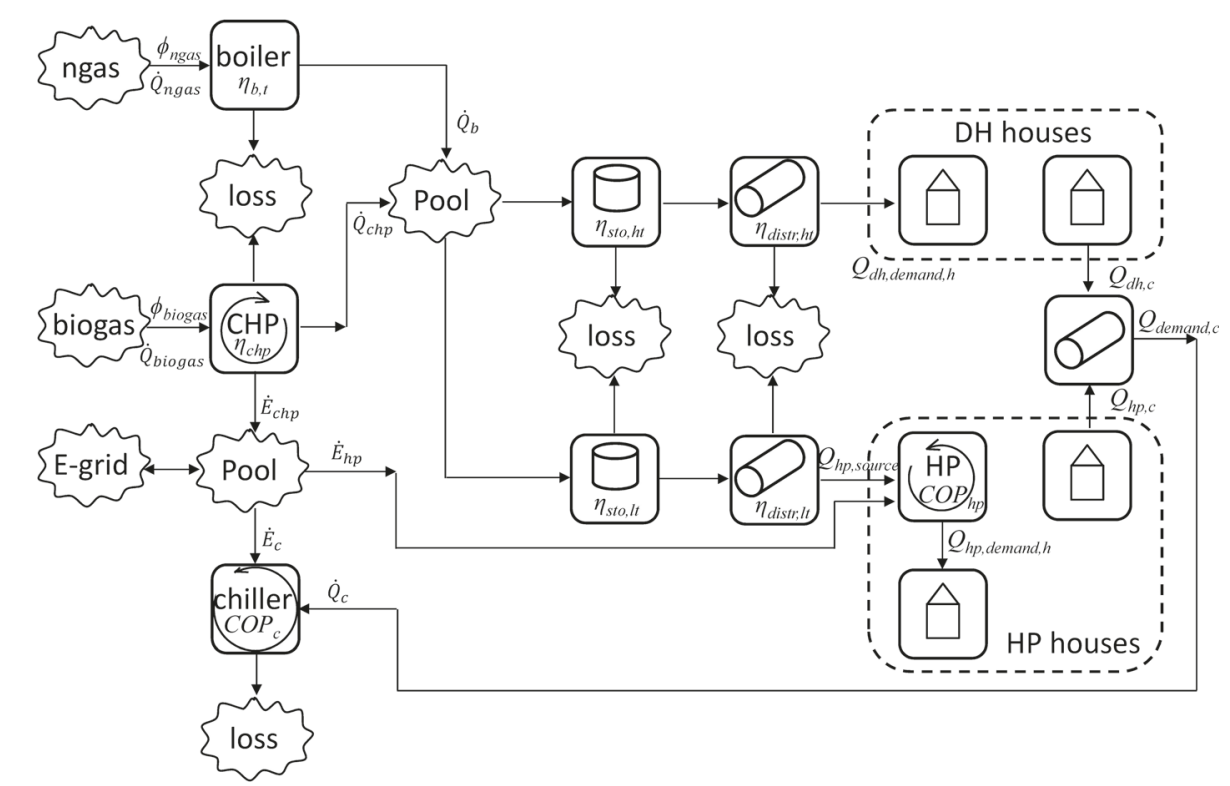

Figure 1 Meppel district heating system starting concept. 
CHP size in relation to varying electricity prices. In a similar study, Cho et al. [5] determine with a linear programming model, for a micro CHP an optimal control scheme to reach economic optimal operation. Chinese et al. [6] develop two optimization models to investigate the design of biomass based district heating networks in Italy in relation to profit maximization and greenhouse gas minimization. The optimization is applied to the design of a new industrial district heating network. Curti et al. [7] investigate configurations for district heating heat pumps which draw low temperature heat from Swiss lakes, supported by cogeneration. They use genetic algorithms to find optimal system sizes. Hlebnikov et al. [8] investigate different scenarios to renovate an existing Estonian district heating network and they apply EnergyPLAN and RETScreen softwares. Lund et al. [9] investigate the role of district heating for the future energy system of Denmark, developing a model of the Danish energy system in EnergyPLAN. Pirouti [10] develops a nonlinear programming model to design district heating networks which are minimized on total energy and exergy consumption and operational costs. Finally, Østergaard [11] reports on the regional energy system of the Danish city Frederikshavn in which an EnergyPLAN model of the region's energy production and consumption is used to predict the outcome of geothermal energy application.

Most authors develop specific models for optimization of case specific energy systems, while others apply modeling capabilities of specific software like EnergyPLAN or RETScreen. Both approaches require specific input generation, e.g., home heating and cooling demand, energy price, and tax schemes. Besides that, constraints of the energy supply system are required, e.g., amount of available biogas, supplying order between the CHP and boilers, and system efficiencies. We consider using EnergyPLAN at a later stage of our research. Due to the complexity involved, we develop our own optimization model within this paper which at a later stage serves as validation tool for results generated by EnergyPLAN.

An important difference between the optimization carried out in, e.g., the papers of Vallios et al., Ren et al., Chinese et al., and Curti et al. and our optimization is that we have limited the amount of variables by developing an additional constraint which relates size of each generator (CHP, boiler) to its operational time. Another difference is that within the present paper, our focus is not limited to technical size but also to compare energy concepts on profit and sustainability performance.

\section{Methods}

\section{District heating system energy model}

The starting concept of the DH system is characterized by converter efficiencies, energy sources, energy demands, and energy flows, as indicated in Figure 1. In the following, we develop an energy balance model for which the nomenclature is given in Table 1.

Efficiency of the thermal storage is determined by the size, the wall insulation, and the average temperature difference between water within the storage and outside air. For the model, we assume that the size of the storages is sufficient to store and supply thermal energy within a daily cycle. As a rule of thumb, $125 \mathrm{~L} /$ household storage capacity is estimated for a DH system with maximum storage temperature of $90^{\circ} \mathrm{C}$. With this, we determine an average storage efficiency. Hence, capacity or size of the storage is not a variable within the model.

The DH system is conceived as a utility which buys energy (biogas, natural gas) from the upstream market, converts it to electricity and heat, and sells heat to the

\section{Table 1 Nomenclature energy concept}

\begin{tabular}{|c|c|}
\hline Term & Signification \\
\hline$\eta_{\mathrm{chp}, e,} \eta_{\mathrm{chp}, t}$ & CHP electric and thermal efficiency \\
\hline$\eta_{b, t}$ & Boiler thermal efficiency \\
\hline$\eta_{\text {sto,ht }}$ & $\begin{array}{l}\text { High temperature }(\mathrm{HT}) \text { thermal storage average } \\
\text { efficiency }\end{array}$ \\
\hline$\eta_{\text {sto,lt }}$ & $\begin{array}{l}\text { Low temperature (LT) thermal storage average } \\
\text { efficiency }\end{array}$ \\
\hline$\eta_{\text {distr }}$ & DH distribution network average efficiency \\
\hline $\mathrm{COP}_{\mathrm{hp}}$ & $\begin{array}{l}\text { Heat pump (HP) coefficient of performance } \\
\text { (COP) }\end{array}$ \\
\hline $\mathrm{COP}_{c}$ & Refrigeration chiller COP \\
\hline$f_{\text {netw }, p}$ & $\begin{array}{l}\text { Fraction of required electric pump energy for } \\
\text { network pumps related to transmitted thermal } \\
\text { energy of the network }\end{array}$ \\
\hline$\phi_{\text {biogas }} \phi_{\text {ngas }}$ & $\begin{array}{l}\text { Biogas supply to CHP, natural gas supply to } \\
\text { boilers }\left(\mathrm{m}^{3} / \mathrm{h}\right)\end{array}$ \\
\hline LHV & Lower heating value $\left(\mathrm{MJ} / \mathrm{m}^{3}\right)$ \\
\hline$\dot{Q}_{\text {biogas }}$ or $\dot{Q}_{\text {ngas }}$ & Fuel-related thermal energy input (kW) \\
\hline$Q_{\mathrm{dh}, \text { demand }, h}$ & $\begin{array}{l}\text { Total DH heating demand of }(n) \text { connected } \\
\text { houses (GJ) }\end{array}$ \\
\hline$Q_{\text {hp,demand, } h}$ & $\begin{array}{l}\text { Total heating energy demand of }(m) \text { houses } \\
\text { with a heat pump }(\mathrm{GJ})\end{array}$ \\
\hline Qhp,source & $\begin{array}{l}\text { Total low temperature source heat for the heat } \\
\text { pumps (GJ) }\end{array}$ \\
\hline$Q_{\text {dhw }}, Q_{\text {sh }}$ & $\begin{array}{l}\text { Domestic hot water demand and space heat- } \\
\text { ing demand (GJ) }\end{array}$ \\
\hline$Q_{\text {demand,c, }} Q_{\mathrm{dh}, c}, Q_{\mathrm{hp}, c}$ & $\begin{array}{l}\text { Cooling energy demand, for DH network } \\
\text { houses, for houses with heat pumps (GJ) }\end{array}$ \\
\hline$\dot{E}_{\text {chp }}$ & CHP electric rated power (kW) \\
\hline$\dot{Q}_{\text {chp }}$ & CHP thermal rated power (kW) \\
\hline$\dot{Q}_{b}$ & Boiler thermal rated power $(\mathrm{kW})$ \\
\hline$t_{\mathrm{op}, \mathrm{chp}}$ and $t_{\mathrm{op}, b}$ & $\begin{array}{l}\text { Full load operational hours of the CHP and } \\
\text { boiler (h/year) }\end{array}$ \\
\hline$\dot{E}_{c}, \dot{Q}_{c}$ & $\begin{array}{l}\text { Refrigeration chiller electric rated power and } \\
\text { cooling rate (kW) }\end{array}$ \\
\hline
\end{tabular}


downstream market, i.e., the households. The electricity is used by circulation pumps and by heat pumps. Surplus electricity produced by the CHP and not used by the local energy system is sold to the grid. Our first emphasis is on the primary choice between either a DH system with only natural gas boilers or with a biogas $\mathrm{CHP}$ and some supporting natural gas boilers.

Besides differences in capital and operational costs of the generators, we have to take cost differences of the downstream system (i.e., storage and network assets) into account caused by the type of converter being applied. The network assets are not influenced but we expect a larger HT storage in case of a CHP. When only boilers are applied, it is easy to adjust the generated thermal power instantly within a large range due to cascading and power modulation. With a CHP the thermal modulation range is not as large and part-load conditions lead to a loss of electrical generation efficiency. Besides that, for best efficiency and lifetime performance, a CHP should run more or less continuous when it runs and should not constantly follow the actual demand of the network. Therefore, increased HT storage capital costs are calculated for the CHP case.

Based on average climatic data, the model determines the base generator sizes for heating (CHP, boilers). How this is done is explained in the 'Relation between CHP size and operational time' subsection. In practice, an additional peak boiler is added to provide sufficient heating capacity during extremely cold days which occur infrequently. The peak boiler capacity is calculated from the coldest day during the last 5 years. For cooling, we determine the generator size directly from the warmest day during the last 5 years.

We assume energy tariffs (natural gas, electricity) are only related to total yearly amounts, although on the electricity spot market and day ahead market, prices vary hourly. But these variations are small and often fixed electricity prices are contracted for longer periods. In this way, the complexity and the number of required iterations for the optimization problem to find the number of houses for break even profit is significantly reduced.

The yearly heat balance for the converters is:

$\left[\frac{Q_{\mathrm{dh}, \mathrm{demand}, h}}{\eta_{\mathrm{distr}} \cdot \eta_{\mathrm{sto}}}+Q_{\mathrm{hp}, \mathrm{source}}\right] \cdot \frac{10^{6}}{3,600}=\dot{Q}_{\mathrm{chp}} \cdot t_{\mathrm{op}, \mathrm{chp}}+\dot{Q}_{b} \cdot t_{\mathrm{op}, b}$

When the CHP and the boilers together generate the required heat, the $\mathrm{CHP}$ has priority and the boilers have a supportive function. Hence, an additional expression is required which relates the operational hours of the CHP to the size of the CHP, which is developed in the 'Relation between CHP size and operational time' subsection.
The total yearly heat demand of the DH system ( $\left.Q_{\mathrm{dh}, \mathrm{demand}, h}\right)$ is related to the average household heat demand. For the average household demand, suitable expressions are developed in the 'Thermal demand specification' subsection. The following relation applies for $n$ houses:

$$
Q_{\mathrm{dh}, \mathrm{demand}, h}=n \cdot Q_{\mathrm{dh}, \mathrm{hhdemand}, h}
$$

Equally, for $m$ houses heated with heat pumps the following relation applies:

$$
Q_{\text {hp,demand, } h}=m \cdot Q_{\text {hp,hhdemand, } h}
$$

The source heat demand of the heat pumps is related to the household demand by:

$$
Q_{\mathrm{hp}, \text { source }}=Q_{\mathrm{hp}, \mathrm{demand}, h} \cdot\left[1-\frac{1}{\mathrm{COP}_{\mathrm{hp}}}\right]
$$

CHP heat generation rate is related to $\mathrm{CHP}$ electric power rate as follows:

$$
\dot{Q}_{\text {chp }}=\dot{E}_{\text {chp }} \cdot \frac{\eta_{\text {chp,th }}}{\eta_{\text {chp }, e}}
$$

The biogas and natural gas flows are related to the CHP electric and boiler thermal power rate, respectively, as follows:

$$
\begin{array}{r}
\phi_{\text {biogas }}=\frac{\dot{E}_{\text {chp }} \cdot 3,600}{\eta_{\text {chp }, e} \cdot \mathrm{LHV}_{\text {biogas }} \cdot 1,000} \\
\phi_{\text {ngas }}=\frac{\dot{Q}_{b} \cdot 3,600}{\eta_{b, \text { th }} \cdot \mathrm{LHV}_{\text {ngas }} \cdot 1,000}
\end{array}
$$

The total yearly electric energy demand including generation of cooling energy is as follows:

$$
\begin{aligned}
E_{\text {demand }} \cdot \frac{3,600}{10^{6}}= & Q_{\mathrm{hp}, \mathrm{demand}, h} \cdot\left[\frac{1}{\mathrm{COP}_{\mathrm{hp}}}+f_{\text {netw }, p}\right] \\
& +f_{\text {netw }, p} \cdot Q_{\mathrm{dh}, \text { demand }, h} \\
& +Q_{\text {demand }, c} \cdot\left[f_{\text {netw }, p}+\frac{1}{\mathrm{COP}_{c}}\right]
\end{aligned}
$$

$f_{\text {netw, } p}$ is an estimated average percentage which discounts the required electric pump energy for network pumps as a percentage of the thermal energy transmitted through the piping network. Real pump energies are to be estimated from network fluid friction calculations and frequency controlled pump characteristics. A value of $5 \%$ is derived from practical calculations.

\section{Optimization model equations}

Financial profit of the starting energy concept shown in Figure 1 is analyzed with an equation in which profit terms are considered related to selling energy to houses (heating and cooling) and to the network (surplus CHP electricity). 
Cost terms that we take into account are as follows: the input energy costs (fuel and bought electricity) and the true capital and operational costs of specific energy generators (boilers, CHP, heat pumps, and related storages). In Table 2, the nomenclature of the profit function is given. We excluded infrastructural costs of the downstream network because in practice, all infrastructural investments are payed for by homeowners through connection fees, so these are not carried by the utility. However, there are also financial reservations to be made for re-investments in the infrastructure and in that case, there is a difference between the DH system and heat pumps as the infrastructure for the heat pumps is relatively cheaper. This difference is accounted for in the fixed part of the heat tariff and is translated into additional income in the case of heat pumps. We explain this in the 'Profit rate for selling heat' subsection.

The equation which expresses the net yearly profit as objective function for maximization is defined as follows:

$$
\begin{aligned}
P_{\text {net }}= & P_{E, \text { grid,sell }}+P_{Q, \mathrm{dh}, h}+P_{\mathrm{Q}, \mathrm{hp}, h}+P_{\mathrm{Q}, \mathrm{dh}, c}+P_{\mathrm{Q}, \mathrm{hp}, c} \\
& -C_{E, \text { grid,buy }}-C_{\text {biogas }}-C_{\text {ngas }}-\sum_{j}\left\{C_{\mathrm{cap}, j}+C_{\mathrm{op}, j}\right\} \\
j \in & \left\{\text { chp, } b, \mathrm{hp}, \text { sto }_{\text {chp }}, \text { sto }_{\mathrm{hp}}\right\}
\end{aligned}
$$

Electricity generated by the CHP is partly consumed by the electric equipment of the $\mathrm{DH}$ network (pumps, heat pumps, chiller). One of the objectives of the smart grid control is to balance power generation and consumption

\begin{tabular}{|c|c|}
\hline Term & Signification (unit: $€ /$ year) \\
\hline$P_{E, \text { grid,sell }}$ & Profit made on electricity sold to the grid \\
\hline$P_{Q, \mathrm{dh}, h}$ & $\begin{array}{l}\text { Profit made on heat sold through the } \mathrm{DH} \\
\text { network }\end{array}$ \\
\hline$P_{Q, h p, h}$ & $\begin{array}{l}\text { Profit made on heat sold to houses fitted with } \\
\text { a heat pump }\end{array}$ \\
\hline$P_{Q, \mathrm{dh}, \mathrm{c}}$ & $\begin{array}{l}\text { Profit made on cooling sold through the } \mathrm{DH} \\
\text { network }\end{array}$ \\
\hline$P_{Q, h p, c}$ & $\begin{array}{l}\text { Profit made on cooling sold to houses fitted } \\
\text { with a heat pump }\end{array}$ \\
\hline$C_{E, \text { grid,buy }}$ & Costs of electricity bought from the grid \\
\hline C biogas & Costs of biogas supply to the DH system \\
\hline Cngas & Costs of natural gas supply to the DH system \\
\hline$C_{\text {cap } j}$ & $\begin{array}{l}\text { Capital costs of investments and required } \\
\text { future re-investments into specific equipment } \\
\text { type } j\end{array}$ \\
\hline$C_{\mathrm{op} j}$ & $\begin{array}{l}\text { Operational costs (operator, maintenance, } \\
\text { insurance, etc) of specific equipment type } j\end{array}$ \\
\hline chp, b, hp, sto chp $_{\text {, stohp }}$ & $\begin{array}{l}\text { Specific equipment: CHP, boiler, heat pump, } \\
\text { storage related to the CHP, storage related to } \\
\text { the heat pumps }\end{array}$ \\
\hline
\end{tabular}
as much as possible. The objective is to match the daily

\section{Table 2 Nomenclature profit function}

$\mathrm{CHP}$ operating times with the operating times of electric and thermal consumers. The smaller the CHP, the longer it will run daily and the higher the chance of matching its generation power with consumption. Therefore, we have implemented a simple algorithm which calculates the fraction of CHP operating time matching operational times of electrical demand by the heat pumps, chiller, and network pumps. This is combined with an algorithm that determines the electricity costs and profit for buying energy from the grid and feeding into the grid.

Investment capital rate $I$ and investments (INV) (unit: $€)$ for the CHP, boiler, heat pumps, and storage are related to size or capacity and are described with power functions. Suitable power function coefficients are obtained from cost engineering handbooks, field experts, and company quotations.

Capital costs are expressed as net present value and are determined by initial investments, the interest rate $r$ which we assume the same for all equipment, and equipment life time (LT) are as follows:

$$
C_{\text {cap }, j}=\operatorname{INV}_{j} \frac{r}{1-\frac{1}{(1+r)^{\mathrm{LT}_{j}}}} \quad j \in\left\{\mathrm{chp}, b, \mathrm{hp}, \text { sto }_{\mathrm{hp}} \text {, } \text { sto }_{\mathrm{chp}}\right\}
$$

Operational costs for each equipment are assumed as a fixed percentage of the initial investment.

\section{Thermal demand specification \\ Approach and assumptions}

Thermal demand includes demand for domestic hot water and space heating. As the district does not yet exist, we develop a straightforward design calculation method in subsequent sections to generate an average demand profile from average daily ambient temperature data for the district.

\section{Domestic hot water demand}

For a district, the demand is determined by the amount of households and the number of persons per household. The following equation based on [12] expresses the variation of daily heat demand for domestic hot water due to holidays throughout the year:

$$
\begin{aligned}
Q_{\mathrm{dhw}, i}= & n Q_{\mathrm{dhw}, \mathrm{av}}+n(1-p) Q_{\mathrm{dhw}, \mathrm{av}} \\
& \times \cos \left(\frac{2 \pi}{365}[i-\text { day_shift }]\right) \\
& i \in\{1, \ldots, 365\}
\end{aligned}
$$

In which $n$ the number of households, $p$ the fraction of households not on holiday during the holiday season, and day_shift the number of days that the minimum of the cosine function (peak day of the holiday season with the least domestic hot water demand) is shifted forward from the first of July. In reality, demand profiles are not smooth 
functions, hence a random daily variation on the profile is generated between $80 \%$ and $120 \%$. This is shown in the case application in the subsequent subsection.

\section{Equations for space heating demand}

The energy demand for space heating can be predicted by taking a number of assumptions into account:

- Heat loss to the environment. In general, the method we apply to construct a daily demand profile is to relate space heating demand to the temperature difference between a constant base temperature $\left(T_{\text {base }}\right)$ and the average daily ambient temperature $\left(\bar{T}_{a, i}\right)$. The base temperature is defined as the average daily ambient temperature for which no space heating is required. Due to solar and internal thermal gains within the interior of a house, the base temperature is lower than the heating setpoint temperature and can be found from experience (i.e., observed number of heating days) or dynamic simulation. The following constraints signifying the space heating demand limit apply:

$$
\Delta T_{\text {heat }, i}= \begin{cases}T_{\text {base }}-\bar{T}_{a, i} & \text { if }\left(T_{\text {base }}-\bar{T}_{a, i}>0\right. \\ 0 & \text { if }\left(T_{\text {base }}-\bar{T}_{a, i} \leq 0\right.\end{cases}
$$

- For the daily sum of the space heating demand, $Q_{\text {sh }, i}$ (unit MJ/day), a simple prediction profile for a single household is constructed from the following relation:

$$
Q_{\text {sh }, i}=U \Delta T_{\text {heat }, i}
$$

In which parameter $U$ (unit $\mathrm{MJ} / \mathrm{K}$ ) is a constant total heat transfer coefficient, signifying all heat loss to the ambient due to envelope conduction, air ventilation and infiltration, and gains by solar radiation, residents, and appliances. $U$ is determined from a known yearly sum of space heating demand as follows:

$$
U=\frac{\sum_{i} Q_{\text {sh }, i}}{\sum_{i} \Delta T_{\text {heat }, i}}
$$

- The yearly sum $Q_{\text {sh }}$ (unit MJ/y) indicated in Equation 13 is determined either by simulation, from literature or energy performance coefficient (EPC) calculation tools which are developed specifically for Dutch houses. We used the EPC verification tool EPG \& Kosten [13] which is distributed by the Dutch government free of charge. Within this tool, various house types (AgentschapNL reference houses, [14]) with reference dimensions based on comparative studies are defined. Building and installation details can be selected and the program calculates the relevant yearly energy demands, based on EPC reference calculations, involving the reference Dutch climate year. The EPC value is the most important parameter for determining the yearly space heating demand. According to current building regulations, an EPC value of 0.4 will be effective from 1 January 2015 for all newly built houses within the Netherlands. Houses within a district heating system which is based on renewable energy receive an EPC reduction, according to [15]. An equivalent generation efficiency of the DH system is calculated with a calculation tool [16], also distributed by the Dutch government.

\section{Case related thermal demand specification}

Based on the methodology developed in the previous subsections, the following specific parameters are defined for the Meppel case:

- Domestic hot water demand. Blokker and Poorteman [17] investigate hot water patterns of an urban district built in 2002 which consists of 3,000 houses. The population composition (age, type of households) compares with the target population of the Meppel case. On average, 2.6 persons per household are calculated. According to [17], [18], and [19] the daily hot water demand per person is 60 $\mathrm{L} /$ day of $45^{\circ} \mathrm{C}$. With an average cold water supply temperature of $12^{\circ} \mathrm{C}$, this amounts to $8.3 \mathrm{MJ} /$ day . person and for an average household of 2.6 persons, this yields $Q_{\mathrm{dhw}, \mathrm{hh}}=21.6 \mathrm{MJ} /$ day and $7.88 \mathrm{GJ} /$ year.

- Space heating and cooling demand. Ambient temperature data for Meppel is taken from weather station in Hoogeveen which is close to Meppel. We determine the average daily temperature for the preceding 5 years. By comparing with simulations, we calculate $T_{\text {base }}=14^{\circ} \mathrm{C}$. The number and type of houses is estimated from the current progress of the Meppel house building project. The target EPC value is estimated at 0.4. A mixed DH system based on biogas $\mathrm{CHP}$ and natural gas boilers yields an equivalent generation efficiency of 1.5 and results in an EPC reduction of 0.15. Hence, we estimate that the real heat demand of houses is designed for an EPC value of 0.55 . With this, the heating and cooling demand values presented in Table 3 are calculated. The resulting district heating demand profile per average household is shown in Figure 2. The profile is constructed by applying Equations 12 and 10 which are added together. The cooling demand profile is shown in Figure 3.

\section{Relation between CHP size and operational time}

When a CHP is operated, it is supported by boilers. A suitable size relation between CHP and boiler size is determined from the coldest day generation balance:

$\dot{Q}_{\max }=\dot{Q}_{\mathrm{chp}}+\dot{Q}_{b}$ 
Table 3 District household space heating and cooling parameters

\begin{tabular}{lccccc}
\hline House type & \% of houses & $\boldsymbol{Q}_{\text {sh,year }}(\mathbf{G J})$ & $\boldsymbol{U}_{\mathbf{s h}}(\mathbf{M J} / \mathbf{K})$ & $\boldsymbol{Q}_{\boldsymbol{c}, \text { year }}(\mathbf{G J})$ & 10.8 \\
\hline Apartment & 14 & 12.2 & 6.38 & $\boldsymbol{U}_{\boldsymbol{c}}(\mathbf{M J} / \mathbf{K})$ \\
Terraced house & 57 & 15.3 & 8.00 & 4.6 & -41.4 \\
Corner house & 29 & 20.3 & 10.62 & 9.2 & -17.7 \\
Average DH house & & 16.3 & & 6.8 & -35.3 \\
Average HP house & & 21.1 & & 6.0 \\
\hline
\end{tabular}

On the coldest day, both heat generators will run continuously for $24 \mathrm{~h}$ to generate the required thermal energy. Hence, the following relation between the heat demand and required peak thermal power applies for the coldest day:

$$
\dot{Q}_{\max }=\max \left[\frac{Q_{\mathrm{dh}, \text { demand }, h}}{\eta_{\text {distr }} \cdot \eta_{\text {sto }}}+Q_{\text {hp,source }}\right]_{1}^{365} \cdot \frac{10^{6}}{3,600 \cdot 24}
$$

If the daily heat demand data is sorted to a data array $Q_{\text {demand }}$ from days with the largest to the smallest heat demand, Equation 15 is equal to the first value in this array. In Figure 4, the sorted array is drawn. We have also drawn the shaded heat demand coverage of a certain $\mathrm{CHP}$ which has just enough capacity to generate the heat demand indicated with a dot. The remaining area above the dotted line is covered by natural gas boilers.

For the sorted array which we convert from GJ/day to kWh/day, let $\dot{Q}_{i}$ be a variable CHP generation capacity such that on day $i$, 24-h operating time with this capacity results in exactly the heat demand of that day, i.e.,
$Q_{\text {demand, } i}$. For the shaded area of Figure 4, it can be demonstrated that the following equations determine the yearly operating time $t_{\text {op }}$ for CHP generation capacity $\dot{Q}_{i}$ :

$$
\begin{aligned}
\dot{Q}_{i} & =\frac{Q_{\text {demand }, i}}{24} ; i \in\{1, \ldots, 365\} \\
t_{o p} & =\frac{\sum_{j \geq i} Q_{\text {demand }, i}}{\dot{Q}_{i}}+24 \cdot i
\end{aligned}
$$

In this relation, $\dot{Q}_{i}$ can be any CHP thermal capacity between 0 and $\dot{Q}_{\max }$. Equation 16 then yields the operating time of that CHP. Figure 5 shows the resulting relation between CHP size and its full power total operation time for the whole year, $t_{\mathrm{op}, \mathrm{chp}}$, calculated with Equation 16.

\section{Case related energy cost parameters Profit and cost rate of electricity}

In the Meppel case, the utility company Meppel Energie buys electric energy from the grid and in case of a CHP it will also feed in surplus electricity into the grid. Contractual buying and selling prices of energy are usually based

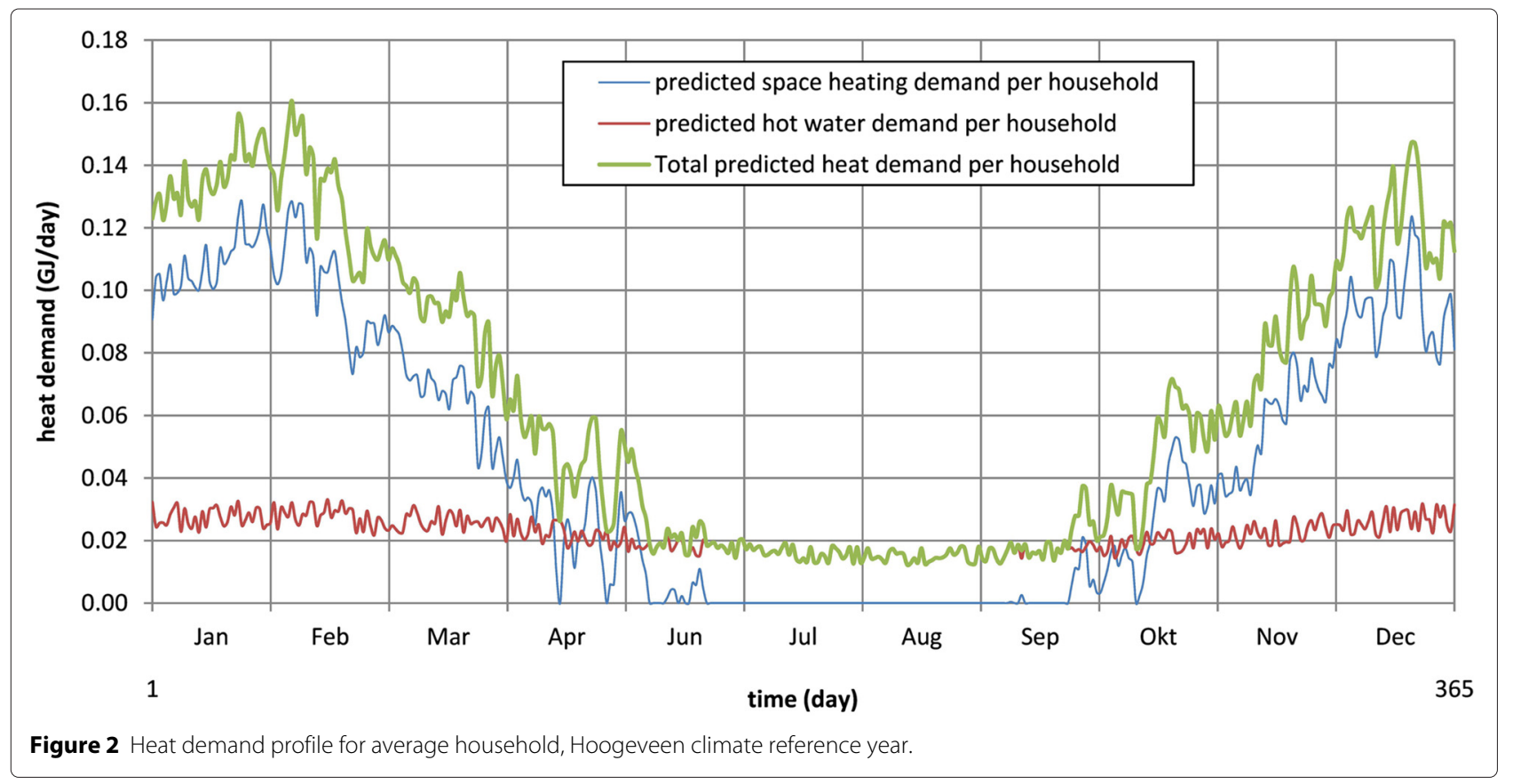




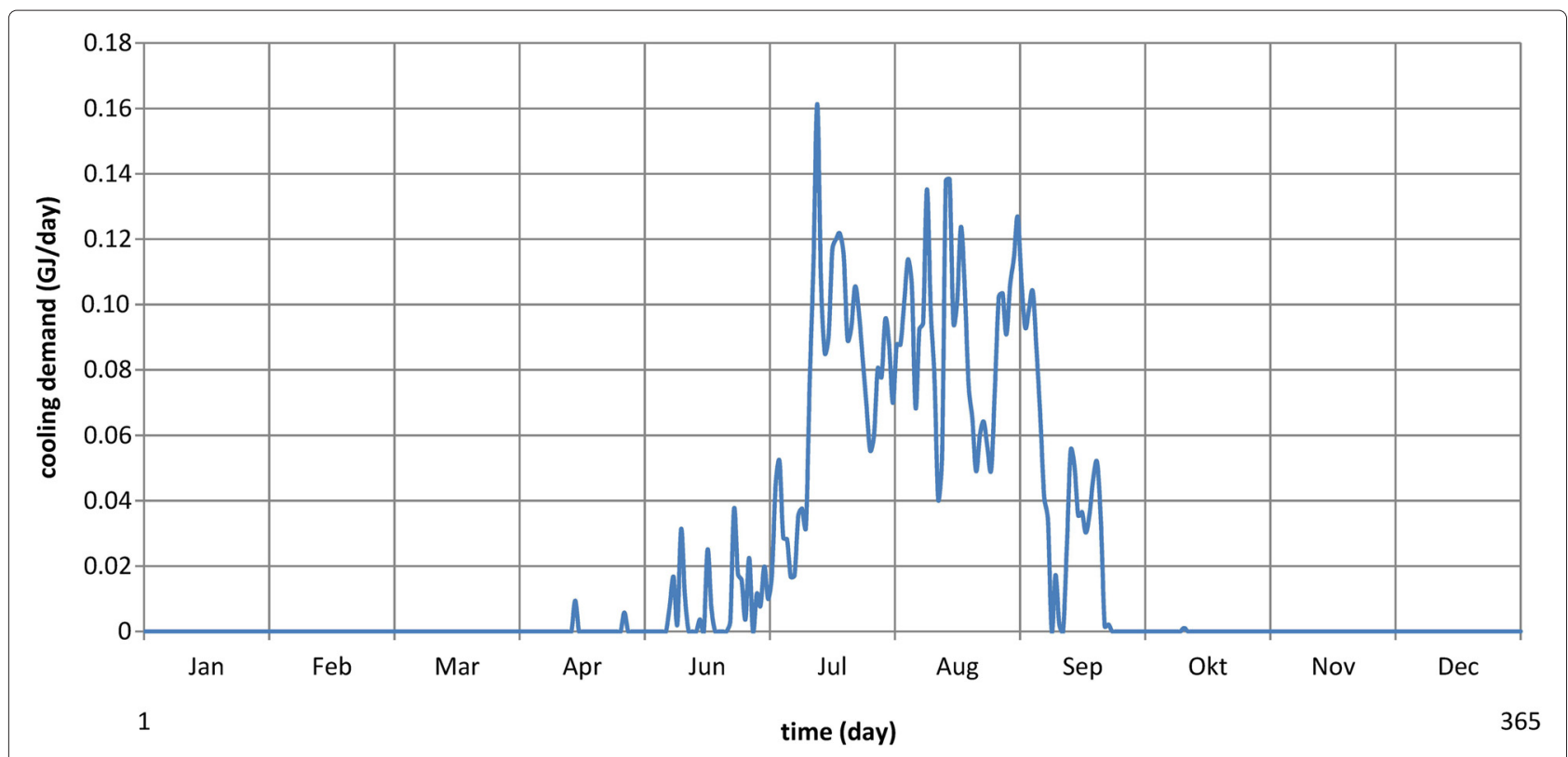

Figure 3 Cooling demand profile for average household.

on the expected amount of energy drawn from and fed into the grid within a certain time period. Following Dutch CHP practice, we assume the buying and selling prices are equal for equal amounts of energy transported to and from the grid over the period of 1 year.

In general, the price of energy drops when the amount of energy being bought increases. For very large amounts (i.e., above $500.000 \mathrm{kWh}$ /year) electricity prices are close to the spot market or day ahead market price of electricity, which is currently around $5.5 € \mathrm{ct} / \mathrm{kWh}$. In case of CHP generation with various electricity consumers, if the amount of sold (surplus) energy exceeds the amount of bought energy, network utilities are often reluctant to pay any compensation, or spot market prices at most. Specific energy price equations are developed for the Dutch situation and implemented into the model.

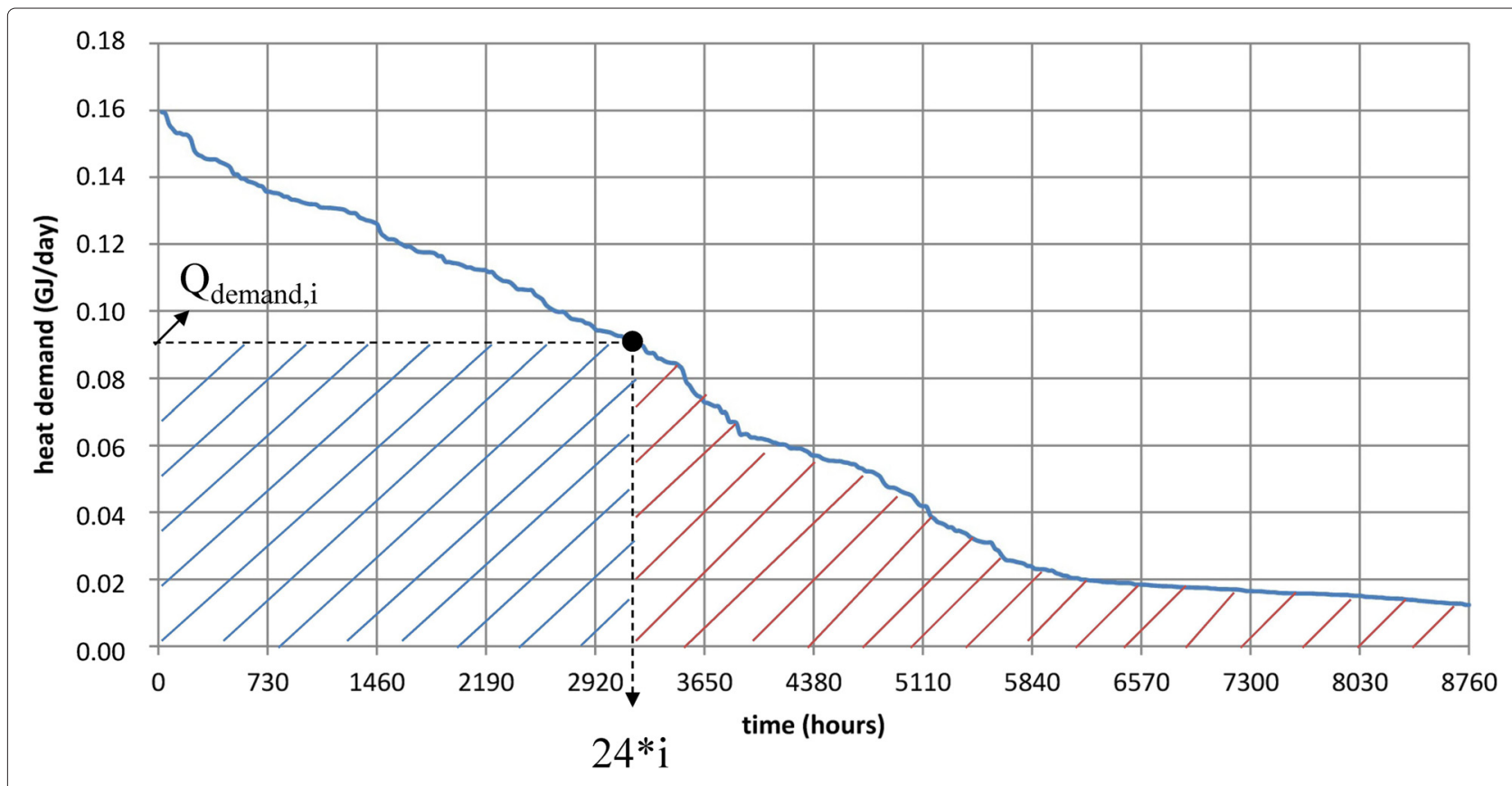

Figure 4 Sorted heat demand and indicated areas at a certain hour point $i$. 


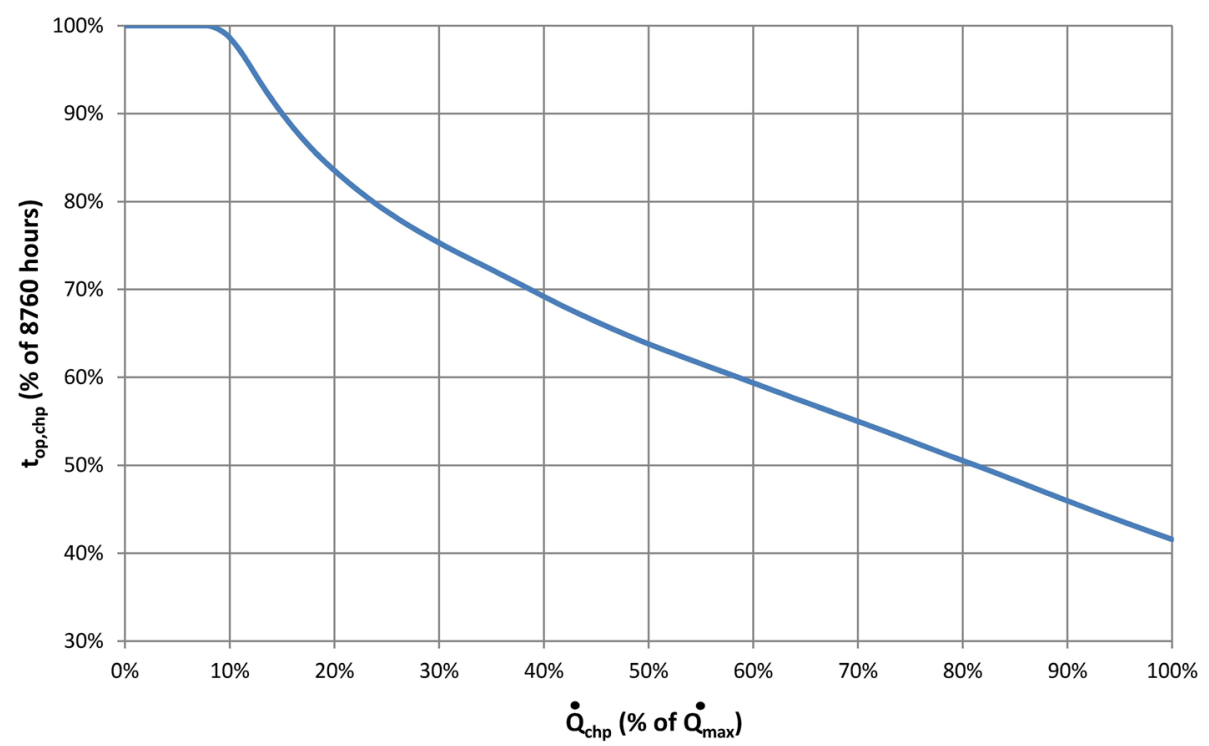

Figure 5 Relation between operational time and CHP size.

\section{Profit rate for selling heat}

As we explain in the 'Optimization model equations' subsection, infrastructural investments are payed off by the residents with a one-time connection fee. This fee is usually part of the building price of a house. Besides the connection fee, residents are charged for the consumed heat according to the following equation, i.e., the Dutch heat law, effective from January 2014 which defines the maximum possible tariff: $P_{Q, h}=209,92+19.86 \cdot Q_{\text {demand, } h}$ (excluding VAT).

Financial reservations have to be made for reinvestments in the required infrastructure. For this, there is a difference between houses connected to the DH system and houses with heat pumps:

- In the case of houses connected to the DH system, we estimate the yearly costs of reservations for infrastructural re-investments at approximately: $€ 146.00$ /(year · household). This leaves as income for the profit model, refer to Equation 8:

$P_{Q, \mathrm{dh}, h}=63.00+19.86 \cdot Q_{\text {demand,dh }, h}$

- In case of houses with a heat pump, we estimate lower reservations for infrastructural re-investments due to the use of non-insulated pipes and a generation building is not required for heat pumps, i.e., $€ 65.00 /($ year-household). This leaves as income: $P_{\mathrm{Q}, \mathrm{hp}, h}=145.00+19.86 \cdot Q_{\text {demand,hp, } h}$.

\section{Profit rate of cooling}

Originally, the Meppel project was planned for a larger starting scale, including the use of the aquifer for cooling energy and source energy for the heat pumps. Cooling of the houses provides part of the required energy to balance temperature of the aquifers and is therefore offered for free to the residents. Meppel energy wants to keep its promise of free cooling to the residents and therefore the profit rate for cooling is $0, P_{Q, c}=0$.

\section{Cost rate of biogas for CHP and natural gas for boilers}

Cost relations for natural gas from the national grid, specific relations for biogas, and applicable energy taxes are developed and implemented as algorithms into the optimization model.

\section{Results and discussion}

\section{Generator and storage capacities}

For the two building phases (phase 1: $40 \mathrm{DH}$ houses; phase 2: $160 \mathrm{DH}$ houses, $16 \mathrm{HP}$ houses) maximum required generation capacity results are shown in Table 4 . The peak boiler capacity mentioned is only required for infrequent extremely cold days and also serves as a heat generation backup in case of CHP or boiler failure or during maintenance periods.

Profit generation, optimal CHP size, and operating times The relation between profit and optimal size of the CHP in relation to boiler size is investigated by maximizing the

Table 4 Calculated generator capacities

\begin{tabular}{lccc}
\hline & $\begin{array}{c}\text { Heat generation } \\
\dot{\mathbf{Q}}_{\max }(\mathbf{k W})\end{array}$ & $\begin{array}{c}\text { Peak boiler } \\
\dot{\mathbf{Q}}_{\boldsymbol{b}, \boldsymbol{p}}(\mathbf{k W})\end{array}$ & $\begin{array}{c}\text { Cooling } \\
\dot{\mathbf{Q}}_{\boldsymbol{c}}(\mathbf{k W})\end{array}$ \\
\hline Phase 1 & 87 & 87 & 74 \\
Phase 2 & 373 & 373 & 322 \\
\hline
\end{tabular}


net profit equation (refer to Equation 8) with $\dot{Q}_{\text {chp }}$ as variable. For the two building phases with $(n, m)$ houses, the optimal sizes in Table 5 are calculated.

Table 5 shows a negative profit for both building phases. Care should be taken in the interpretation of the profit values as they are influenced by assumptions explained in the 'Profit rate for selling heat' subsection. We may have exaggerated the re-investment costs, lacking detailed insight in the Meppel Energie business case. On the other hand, practical experience indicates problematic profitability of small-scale DH systems, which support our results. In the Meppel case, there is more pressure on profitability because the houses have a lower heating demand (and thus lower revenue per household) than usual, and there are generation costs involved for cooling while on the other hand, cooling is offered free of charge. If we calculate a fee for cooling based on break even operation, this yields $€ 64 /$ year and $€ 70 /$ year per household for phases 1 and 2 , respectively. To place this in perspective of what households would normally pay if they generate the required cooling with home-based air conditioning equipment, the average cooling demand of $6 \mathrm{GJ} /$ year requires $555 \mathrm{kWh}$ per household electric energy which would costs each household $€ 127 /$ year only for electricity. Hence, the calculated fees are reasonable propositions to the residents.

What is the influence of houses with heat pumps on the profit? By maximizing the net profit Equation 8 with $\dot{Q}_{\text {chp }}$ and $m$ as variables, we find that for various numbers of $n$ houses, $m=0$. So in all cases, houses with heat pumps have a negative influence on profit. There are two reasons for this. First, in the starting energy concept, the source heat for the heat pumps is generated by the CHP and boilers, with fuel costs as a consequence. Second, individual heat pumps for each house are relatively expensive in comparison with DH delivery sets as HP's require more investments and maintenance and also have a shorter life time. Clearly, the compensation offered by a higher tariff ('Profit rate for selling heat' subsection) is not sufficient for an equally profitable operation of heat pumps compared to houses connected to the DH system.

If the number of houses connected to the DH system expands, when will operation become profitable? This depends mostly on (a) the applied interest rate $r$ and (b) the household heating demand. If $r=4 \%$ then operation breaks even at $n=490$ houses. The corresponding optimal generation sizes and operating times are as follows:
$\dot{E}_{\text {chp }}=426 \mathrm{~kW}, t_{\text {op,chp }}=5,293 \mathrm{~h} /$ year, $\dot{Q}_{b}=448 \mathrm{~kW}$, and $t_{\mathrm{op}, b}=1,340 \mathrm{~h} /$ year. For $r=2 \%$ the break even point is $n=277$ houses.

\section{CHP migration steps}

When the number of houses in the district increases, ideally the CHP and boiler sizes also have to increase according to the optimal profitability found in the previous subsection. It is relatively easy to install more boiler capacity, but replacing or adding a single CHP requires much higher investments and more accompanying equipment. CHP expansion is possible in two ways, either by leasing CHP units for a period of time or by investing in a starting CHP unit and investing into more CHP units when this is required. The latter option has the advantage that CHP capacity is gradually expanded and eventually the generation capacity exists of a number of smaller CHP units, which enables smoother power regulation and operation of each CHP under full load conditions, which is beneficial for fuel efficiency and technical reliability. However, this option requires more investments, although the Dutch tax scheme offers substantial tax reductions for CHP investments, so this is selected as the most interesting approach. Therefore, we investigate the relation between CHP size and profit in four steps from building phase 1 to phase 2 , to estimate the proper CHP sizes. The result is shown in Figure 6.

For each line in the Figure, the value for $(n, m)$ is indicated. Around the optimum of each line, the relation between profit and CHP size is rather flat. This gives flexibility to choose the CHP size according to logical migration steps for the district. An attractive migration route is to start with a 30-kWe CHP for a small district with 40 houses and to install a second, larger CHP, e.g., $140 \mathrm{kWe}$ when 160 houses are connected.

\section{Comparison on sustainability}

Sustainability of the Meppel energy concept shown in Figure 1 is investigated by comparing fossil fuel requirements for building phase 2 ( $n=160, m=16$ houses), for which we define four cases:

1. Case 1: starting energy concept with optimal sized $\mathrm{CHP}$ on biogas supported by a boiler on natural gas. The Sankey or energy flow diagram for this case is shown in Figure 7. Total natural gas input: 1,648

Table 5 Optimal CHP size for building phases 1 and 2

\begin{tabular}{lcccccc}
\hline$(\boldsymbol{n}, \boldsymbol{m})$ & $\begin{array}{c}\text { Profit without } \\
\text { CHP }(€ / \text { year })\end{array}$ & $\begin{array}{c}\text { Optimal CHP } \\
\text { size } \dot{E}_{\text {chp }}(\mathbf{k W})\end{array}$ & $\begin{array}{c}\boldsymbol{t}_{\mathrm{op}, \mathrm{chp}} \\
(\mathbf{h} / \text { year })\end{array}$ & $\begin{array}{c}\text { Boiler size } \\
\dot{Q}_{\boldsymbol{b}}(\mathbf{k W})\end{array}$ & $\begin{array}{c}\boldsymbol{t}_{\mathrm{op}, \boldsymbol{b}} \\
(\mathbf{h} / \text { year) }\end{array}$ & $\begin{array}{c}\text { Profit with } \\
\text { CHP }(€ / \text { year) }\end{array}$ \\
\hline$(40,0)$ & $-6,911$ & 6 & 8,659 & 78 & 3,077 & $-2,571$ \\
$(160,16)$ & $-20,807$ & 100 & 6,140 & 228 & 2,033 & $-12,380$ \\
\hline
\end{tabular}




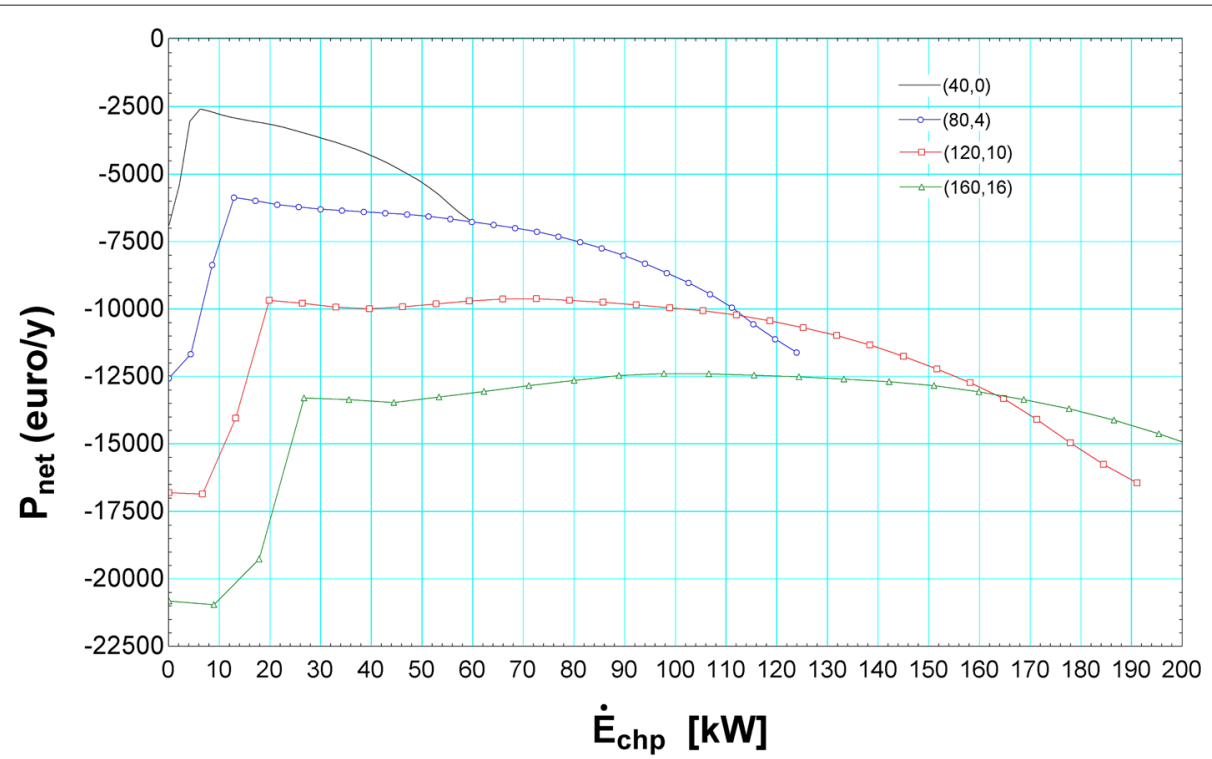

Figure 6 CHP optimum for possible migration steps.

GJ/year. Total biogas input: 6,177 GJ/year. If the $\mathrm{CHP}$ runs on natural gas, the total natural gas input is: $7,825 \mathrm{GJ} /$ year.

2. Case 2: starting energy concept without a CHP. In this case, the boiler delivers 4,860 GJ/year with an equal natural gas input. The required electricity for heat pumps, cooling and network pumps, and energy delivered to the region total 2,222 GJ/year. This requires 4,938 GJ/year of natural gas input at a grid-based electrical power plant, taking Dutch national fuel efficiency of $45 \%$ into account. Hence, total natural gas input: 9,798 GJ/year.

3. Case 3: Dutch conventional house heating by individual home-fitted natural gas boilers. In this case for heating, 4,318 GJ/year natural gas is required. The required electricity for cooling and comparable electricity supplied to the region total $1,816 \mathrm{GJ} /$ year. If a grid-based electrical power plant is used, 4,036 GJ/year natural gas input is required. In that case, the natural gas input totals: 8,354 GJ/year.

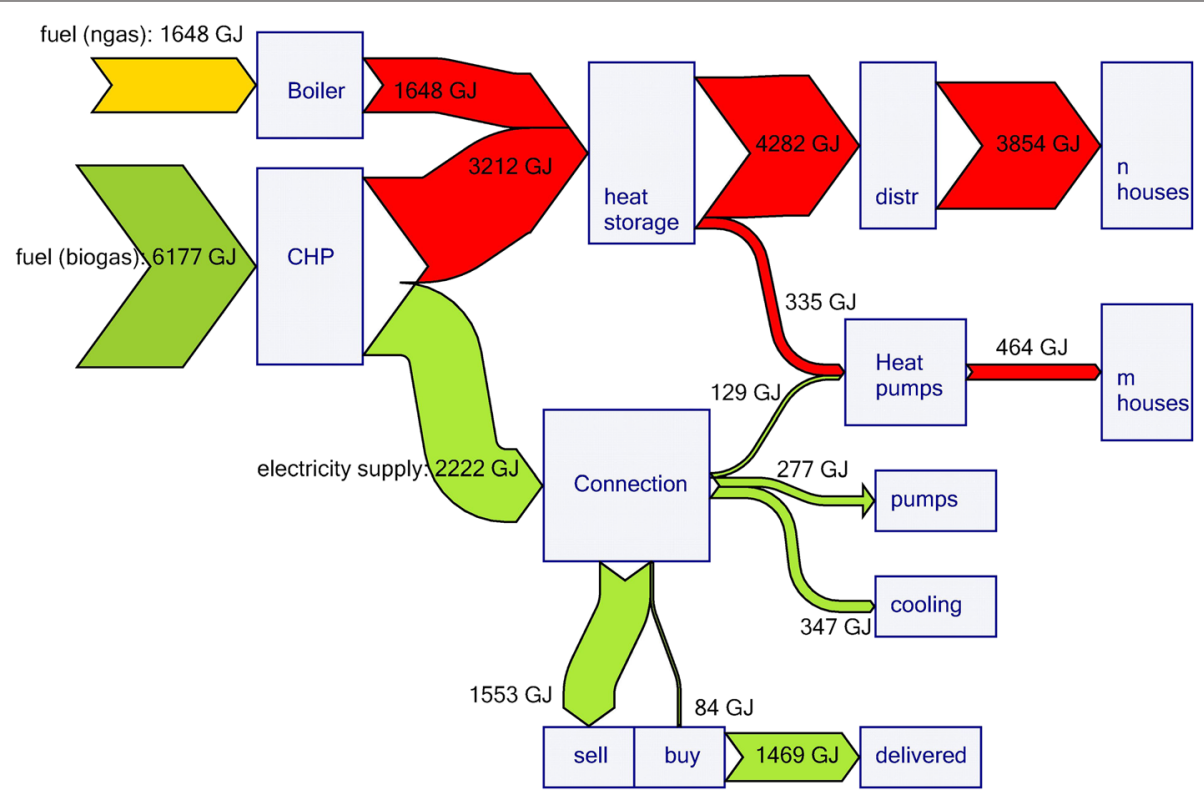

Figure 7 Sankey diagram starting energy concept, building phase 2. 
4. Case 4: as an alternative for case 3, the $1,816 \mathrm{GJ} /$ year electricity is generated by home installed solar PV. For 176 houses, this is $2,866 \mathrm{kWh} /$ year per household. Under Dutch circumstances, this is feasible. Total natural gas input: 4,318 GJ/year only for heating is required.

The resulting natural gas input is shown in Figure 8. Case 1 shows the best sustainability results; however, if natural gas is used for the CHP, the concept is only $6 \%$ more sustainable than case 3, i.e., conventional house heating with natural gas boilers. Case 2 shows that the DH system without a CHP actually has the worst performance on sustainability.

Case 4 with home PV installations is interesting as improved sustainability is combined with less infrastructural investments than case 1 and is hence easier to implement in an unsure house building market. Case 4 also leads to another objective, i.e., to invest into more energy efficient houses, in order to further reduce natural gas consumption. We re-calculated case 4 with passive house $(\mathrm{PH})$ space heating requirements, and this results in the fifth column in Figure 8. This case can be taken further, replacing natural gas boilers with heat pumps. The district then contains passive houses, each with a solar PV roof and a heat pump connected to a ground source or aquifer. Natural gas input is then eliminated totally. The drawback of such a concept however is the imbalance between periods of major PV electricity generation and periods with the highest heating demand. Further comparisons of these concepts including financial aspects and loads on the electricity network are left for future work.

The use of biogas instead of natural gas reduces carbon dioxide $\left(\mathrm{CO}_{2}\right)$ emissions, while biogas is formed with $\mathrm{CO}_{2}$ from the earth's atmosphere and the $\mathrm{CO}_{2}$ is released when the biogas is burned. For natural gas, a conversion factor of $52 \mathrm{~kg} \mathrm{CO} / \mathrm{GJ}$ is derived. Case 1 with biogas results in 86 tons $\mathrm{CO}_{2}$ /year and case 2 in 509 tons $\mathrm{CO}_{2} /$ year. Hence, case 1 results in a $\mathrm{CO}_{2}$ reduction of 423 tons/year.

The last question of interest for the Meppel case is how many houses and what size of the CHP are appropriate if all the available biogas of the municipality (i.e., 9,200 GJ/year) is applied? As optimum, we find $n=232$ houses and $\dot{E}_{\text {chp }}=159 \mathrm{~kW}$. The natural gas input required for boilers is then $1,775 \mathrm{GJ} /$ year, resulting in net $\mathrm{CO}_{2}$ emissions of 92 tons/year. The net profit (or loss in this case) is calculated at $-€ 5,711$ /year. When a cooling fee of $€ 50 /$ year is asked from each household, the net profit is positive, i.e., $€ 5,899 /$ year.

\section{Conclusions}

In this paper, optimal heat and power generation sizes are determined for the new urban district Nieuwveenslanden situated in Meppel for two building phases starting at 40 houses and expanding towards 176 houses. Besides optimal CHP and boiler sizes, we determine corresponding profits and sustainability of the network on fossil fuel requirements. Profits appear to be negative, however more than 50\% improvement is possible if a CHP is used for heat and power generation compared to operation with only boilers. With an interest rate of $4 \%$ on invested capital, profits are positive when more than 490 houses are connected, with $2 \%$ this is reduced to 277 houses. If households are charged a modest fee for cooling, the energy concept with a CHP is profitable from the start. Based on maximizing profit, a migration scenario for the CHP is developed starting with a single $30-\mathrm{kWe}$ CHP for 40 houses connected to the DH system and adding a 140-kWe CHP when 160 houses are connected.

Sustainability of the energy concept is compared with the Dutch reference, i.e., houses heated by individual natural gas boilers. If a CHP on biogas is applied, the Meppel

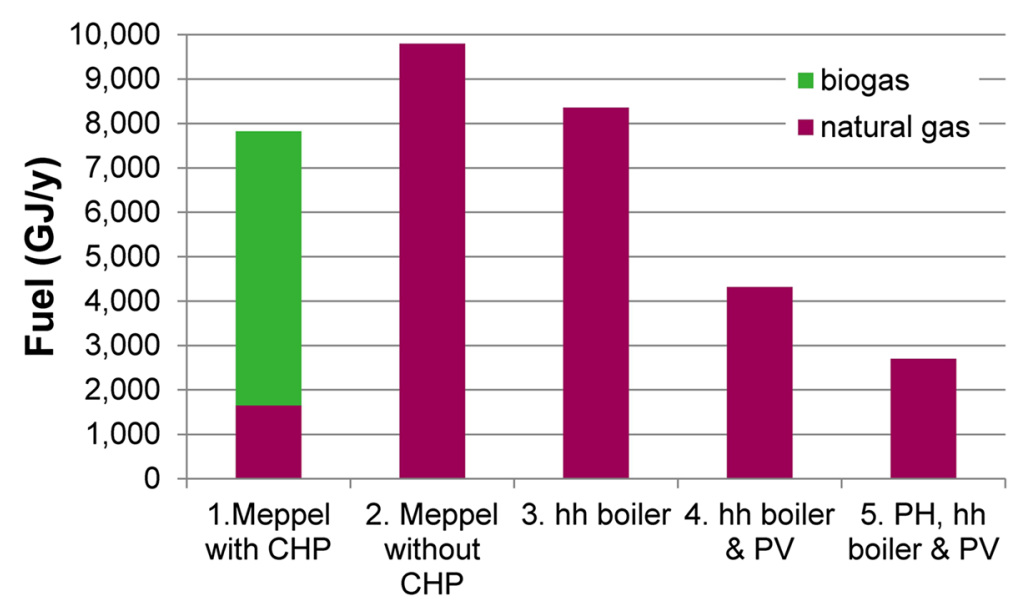

Figure 8 Case-related fuel input comparison. 
energy concept reduces 351 tons $\mathrm{CO}_{2}$ /year or $80 \%$ reduction. However, if the CHP runs on natural gas, the $\mathrm{CO}_{2}$ reduction is only $6 \%$. It has to be considered that a scenario based on the Dutch reference combined with home solar PV is another possible route towards improved sustainability but involves less infrastructural investments. However, the Meppel DH system concept with a CHP on biogas still performs better on sustainability than this alternative route.

For the Meppel DH system, houses with a heat pump have a negative influence on the profitability. This is because individual household heat pumps are more expensive to operate than the $\mathrm{DH}$ system. It is interesting to compare this also for the final energy concept in which source heat and cooling are generated by an underground aquifer. In that case, we expect to reach better profitability. Investigating the final energy concept is left for future work. Also a more comprehensive comparison between the Meppel energy concept and more individual energy generation solutions requiring less infrastructure is left for future work.

\section{Competing interests}

The authors declare that they have no competing interests.

\section{Authors' contributions}

RVL carried out the research for this paper, developed the models, performed all simulations, and drafted the manuscript. JF participated in the model development and critically revised the paper. JDW defined alternative energy systems to compare on sustainability and supplied background case related data to compare with. GS critically revised the paper and gave final approval for the paper to be published. All authors read and approved the final manuscript.

\section{Authors' information}

JF is affiliated to the STW project i-Care and Dream.

\section{Acknowledgements}

The authors would like to thank the Dutch national program

TKI-Switch2SmartGrids for supporting the project MeppelEnergie and the STW organization for supporting the projects i-Care and Dream that resulted in this work.

Received: 23 February 2015 Accepted: 25 April 2015

Published online: 16 May 2015

\section{References}

1. AgentschapNL (2014) Biogas-warmtekrachtkoppeling (WKK) voor Een Wijk. http://www.rvo.nl/onderwerpen/duurzaam-ondernemen/ gebouwen/energieprestatie-nieuwbouw-epn/ontwerpen/ referentiewoningen-nieuwbouw. visited January 2014

2. Schepers BL, Valkengoed MPJV (2009) Warmtenetten in nederland overzicht van grootschalige en kleinschalige warmtenetten in nederland. Technical Report 09.3031.45, CE-Delft http://www.ce.nl/publicatie/ warmtenetten_in_nederland/976, visited May 2015

3. Vallios I, Tsoutsos T, Papadakis G (2009) Design of biomass district heating systems. Biomass and bioenergy 33(4):659-678

4. Ren H, Gao W, Ruan Y (2008) Optimal sizing for residential CHP system. Appl Therm Eng 28(5):514-523

5. Cho H, Luck R, Eksioglu SD, Chamra LM (2009) Cost-optimized real-time operation of CHP systems. Energy and Buildings 41(4):445-451

6. Chinese D, Meneghetti A (2005) Optimisation models for decision support in the development of biomass-based industrial district-heating networks in Italy. Appl energy 82(3):228-254
7. Curti V, Favrat D, von Spakovsky MR (2000) An environomic approach for the modeling and optimization of a district heating network based on centralized and decentralized heat pumps, cogeneration and/or gas furnace. Part II: application. Int J Ther Sci 39(7):731-741

8. Hebnikov A, Dementjeva N, Siirde A (2009) Optimization of Narva district heating network and analysis of competitiveness of oil shale CHP building in Narva. Oil Shale 26:269-282

9. Lund H, Möller B, Mathiesen BV, Dyrelund A (2010) The role of district heating in future renewable energy systems. Energy 35(3):1381-1390

10. Pirouti M (2013) Modelling and analysis of a district heating network

11. Østergaard PA, Lund $H$ (2011) A renewable energy system in Frederikshavn using low-temperature geothermal energy for district heating. Appl Energy 88(2):479-487

12. Jordan U, Vajen K (2001) Realistic domestic hot-water profiles in different time scales. Report for IEA-SHC Task 26. http://sel.me.wisc.edu/trnsys/ trnlib/iea-shc-task26/iea-shc-task26-load-profiles-description-jordan.pdf, visited May 2015

13. RVO (2014) EPG Rekentool. https://www.rvo.nl/onderwerpen/duurzaamondernemen/gebouwen/energieprestatie-nieuwbouw-epn/epcberekenen/hulpmiddelen-epc-berekening?wss\%l=1, visited January 2014

14. AgentschapNL (2013) Referentiewoningen Nieuwbouw 2013 Agentschap NL. http://www.rvo.nl/onderwerpen/duurzaamondernemen/gebouwen/energieprestatie-nieuwbouw-epn/ontwerpen/ referentiewoningen-nieuwbouw visited January 2014

15. AgentschapNL (2014). http://www.rvo.nl/sites/default/files/ Gebiedsmaatregelen\%20voor\%20het\%20eerst\%20gewaardeerd\%20in \%20de\%20EPC_bepaling_0.pdf, visited January 2014

16. RVO (2014) EMG Rekentool. https://www.nen.nl/NEN-Shop/Norm/ Update-rekentool-energieprestatie-gebied-beschikbaar.htm, visited January 2014

17. Blokker EJM, Poortema K (2007) Effecten levering warm tapwater door derden. Technical report, sKIWA

18. Geudens PJJG (2012) Drinkwaterstatistieken 2012. VEWIN 41(4):445-451

19. Blokker EJM (2006) Modelleren van afnamepatronen; beschrijving en validatie van het simulatiemodel simdeum. Technical report, KIWA. http://www.kwrwater.nl/WorkArea/DownloadAsset.aspx?id=8787, visited May 2015

\section{Submit your manuscript to a SpringerOpen ${ }^{\circ}$ journal and benefit from:}

- Convenient online submission

Rigorous peer review

- Immediate publication on acceptance

- Open access: articles freely available online

- High visibility within the field

- Retaining the copyright to your article

Submit your next manuscript at $>$ springeropen.com 